\title{
Study of cocaine seizures through spatial analysis
}

\author{
Estudo das apreensões de cocaína através da análise espacial \\ Estudio de las incautaciones de cocaína mediante el análisis especial
}

Received: 03/05/2021 | Reviewed: 03/12/2021 | Accept: 03/16/2021 | Published: 03/23/2021

\author{
Mayrla Emília Dantas Vasconcelos \\ ORCID: https://orcid.org/0000-0001-6448-2692 \\ Universidade Estadual da Paraíba, Brazil \\ E-mail: mayrlaemilia@usp.br \\ Sayonara Maria Lia Fook \\ ORCID: https://orcid.org/0000-0003-1948-9371 \\ Universidade Estadual da Paraíba, Brazil \\ E-mail: sayonarafook@servidor.uepb.edu.br \\ Ricardo Alves de Olinda \\ ORCID: https://orcid.org/0000-0002-0509-8428 \\ Universidade Estadual da Paraíba, Brazil \\ E-mail: ricardo.estat@yahoo.com.br \\ Nícia Stellita da Cruz Soares \\ ORCID: https://orcid.org/0000-0002-5238-075X \\ Universidade Estadual da Paraíba, Brazil \\ E-mail:ns-soares@uol.com.br \\ Ivana Maria Fechine \\ ORCID: https://orcid.org/0000-0002-0578-1155 \\ Universidade Estadual da Paraíba, Brazil \\ E-mail: ivana.fechine@ servidor.uepb.edu.br \\ Marina Lia Fook Meira Braga \\ ORCID: https://orcid.org/0000-0003-4558-2166 \\ Centro Universitário UNIFACISA, Brazil \\ E-mail: marinafbraga@ hotmail.com
}

\begin{abstract}
Cocaine trafficking and consumption continues to prosper despite the public policies that are in force in Brazil, despite its use for thousands of years, it is currently a public health problem. This study aimed to report the sociodemographic variables of individuals apprehended with cocaine and who were framed in Law $n^{\circ} .11,343$ of August 2006, in the municipality of Campina Grande, in 2017. It was a hybrid study, with a transversal, retrospective cut and ecological, with a quantitative approach. The neighborhood area variable was distributed in thematic maps and the spatial autocorrelation was measured by the Moran Global and Local indexes, which quantify the degree of autocorrelation. 210 cocaine seizures were recorded, of which 146 occurred in the municipality of Campina Grande, of these, only 94 presented all the data and were considered in this study. The months of September $(n=14)$ and October $(n=13)$ had the highest records of seizures. As for the pattern of use, crack in the yellowish stone form was predominant $(n=46)$, followed by cocaine hydrochloride in the form of white powder $(n=40)$. The profile of the individual apprehended with cocaine in the municipality was that of a young, single, unemployed and with low level of education. The predominant framework was drug trafficking $(n=75)$ according to Article $n^{\circ} .33$ of Law $n^{\circ} .11,343 / 2006$. The neighborhoods that registered the highest number of seizures were José Pinheiro $(n=15)$ and Pedregal $(n=8)$. The Moran General and Local indexis ( $p>0.05$ ), did not show spatial dependence between neighboring neighborhoods, that is, there is no autocorrelation for the analyzed variable.
\end{abstract}

Keywords: Cocaine; Seizures; Spatial analysis.

\section{Resumo}

O tráfico e consumo de cocaína continua prosperando a despeito das políticas públicas que estão em vigor no Brasil, apesar de seu uso ser milenar, atualmente é um problema de Saúde Pública. Este trabalho teve como objetivo relatar as variáveis sociodemográficas dos indivíduos apreendidos portando cocaína e que foram enquadrados na Lei ${ }^{\circ}$ 11.343 de agosto de 2006, no município de Campina Grande, em 2017. Tratou-se de um estudo hibrido, com recorte transversal, retrospectivo e ecológico, com abordagem quantitativa. A variável área bairro foi distribuída em mapas temáticos e a autocorrelação espacial foi mensurada pelos índices de Moran Global e Local, que quantifica o grau de autocorrelação. Foram registrados 210 apreensões de cocaína, das quais 146 aconteceram no município de Campina Grande, destas, apenas 94 apresentaram totalidade dos dados e foram consideradas nesse estudo. Os meses de setembro $(\mathrm{n}=14)$ e outubro $(\mathrm{n}=13)$ apresentaram os maiores registros de apreensões. Quanto ao padrão de uso, o "crack" na forma de pedra amarelada foi predominante $(\mathrm{n}=46)$, seguido pelo cloridrato de cocaína na forma de pó 
branco $(n=40)$. O perfil do individuo apreendido com cocaína no município foi de um jovem, solteiro, desempregado e com baixo nível de escolaridade. O enquadramento predominante foi o de tráfico de drogas $(\mathrm{n}=75)$ de acordo com o Artigo $n^{\circ} 33$ da Lei $n^{\circ} 11.343 / 2006$. Os bairros que registraram o maior número de apreensão foram José Pinheiro $(n=15)$ e Pedregal $(n=8)$. Os índices de Moran Geral e Local $(p>0,05)$, não apresentaram dependência espacial entre os bairros vizinhos, ou seja, não existe uma autocorrelação para a variável analisada. Portanto, as apreensões de cocaína aconteceram de forma aleatória no município de Campina Grande, em 2017, ou seja, estatisticamente um determinado bairro, não influencia os circunvizinhos em relação à variável estudada.

Palavras-chave: Cocaína; Apreensões; Análise espacial.

\section{Resumen}

El tráfico y el consumo de cocaína siguen prosperando a pesar de las políticas públicas que se aplican en Brasil, aunque su uso es milenario, actualmente es un problema de salud pública. Este trabajo tuvo como objetivo reportar las variables sociodemográficas de los individuos incautados portando cocaína y que fueron encuadrados en la Ley $\mathrm{N}^{\circ}$ 11.343 de agosto de 2006, en el municipio de Campina Grande, en 2017. Se trata de un estudio híbrido, de corte transversal, retrospectivo y ecológico, con un enfoque cuantitativo. La variable área de vecindad se distribuyó en mapas temáticos y la autocorrelación espacial se midió mediante los índices de Moran Global y Local, que cuantifican el grado de autocorrelación. Fueron 210 incautaciones de cocaína, de las cuales 146 ocurrieron en el municipio de Campina Grande, de éstas, sólo 94 presentaron la totalidad de los datos y fueron consideradas en este estudio. Los meses de septiembre $(n=14)$ y octubre $(n=13)$ presentaron los mayores registros de incautaciones. En cuanto al patrón de consumo, predominó el crack en forma de piedra amarillenta $(n=46)$, seguido del clorhidrato de cocaína en forma de polvo blanco $(n=40)$. El perfil del individuo incautado con cocaína en el municipio era un joven, soltero, desempleado y con bajo nivel educativo. El marco predominante fue el tráfico de drogas (n=75) según el artículo 33 de la Ley 11.343/2006. Los barrios que registraron el mayor número de incautaciones fueron José Pinheiro (n=15) y Pedregal $(n=8)$. Los índices de Moran General y Local ( $>>0,05)$, no mostraron dependencia espacial entre los barrios vecinos, es decir, no existe autocorrelación para la variable analizada. Por lo tanto, las incautaciones de cocaína ocurridas al azar en el municipio de Campina Grande, en 2017, es decir, estadísticamente un barrio en particular, no influye en el entorno en relación con la variable estudiada.

Palabras clave: Cocaína; Incautaciones; Análisis espacial.

\section{Introduction}

In Brazil, the problem of drugs is the subject of discussions in various spheres of public policy, attempts to remedy or control the disorder are recurrent. Until the 1920s, official laws regulating the issue of illicit drugs in the country were nonexistent. At the time of the great industrial explosion and modernization of the country in 2009, the use of drugs, which previously was restricted to some upper-class youths who frequented brothels, started to occupy other social spheres such as low-income people and homeless people, classes considered at the time as dangerous and risky to society (Brasil, 2009).

This spread began to disturb government officials and the Brazilian elite, which promptly, in 1921, implemented a law that forbade the use of opium, morphine, heroin and cocaine in the country, whose accused was liable to severe punishment. The restriction on the use of drugs remains until today, receiving additions and changes over the years according to social need, and thus the reasoning of the public policy framework around the regularization of drug use and narcotics in Brazil begins (Carvalho, 2011).

In the year 1938, based on the aspects discussed in the International Opium Convention signed in The Hague on January 23, 1912, the need to regulate through the Decree-Law $n^{\circ}$. 891, entitled as Narcotics Inspection Law inspection and taking appropriate measures for the use of narcotics, mainly the condemnation of the use of opium and cocaine, in addition to other drugs such as marijuana and heroin. The decree classified addiction to drugs as a "compulsory notification disease", which should be treated in specialized centers and not at home, thus creating a range of psychiatric hospitals, as provided in article $29 \S 1$ st (Rio de Janeiro, 1938).

On October 21, 1976, the repression of illicit trafficking was established through Law nº. 6,368 (Brazil, 1976).

In 1980, the National Narcotics Prevention, Inspection and Repression System was established. The creation of the Federal Narcotics Council (COFEN) was standardized, backed by Decree nº. 85,110 (Federal District, 1980). The creation of COFEN represented the genesis of all public actions related to narcotics still in force. 
Then there was the Fund for Prevention, Recovery and Combating Drugs of Abuse (FUNCAB), which disposes of acquired goods with illicit drug trafficking products or related activities through Law no 7,560 of December 1986 (Brazil, 1986). From FUNCAB came FUNAD - National Anti-Drug Fund.

In order to technically supervise all actions related to combating drug trafficking in 1993, the Ministry of Justice created the Federal Narcotics Secretariat. In 1998 it was renamed the National Anti-Drug Secretariat (SENAD) together with the former CONFEN, which became CONAD - National Anti-Drug Council. Both bodies were separated from the Ministry of Justice and became part of the Military House of the Public Presidency (Brazil, 2019).

Through Decree $n^{\circ} .4,345$ of August 26, 2002, everything that had already been widely discussed was incorporated into the National Anti-Drug Policy (PNAD) (Distrito Federal, 2002). In the same year, Law nº 10,409 of January 11, repealed Law $n^{\circ}$. 6,368 of October 21, 1976, maintaining several points in relation to the reduction in the supply of narcotics (Brasil, 2002).

In an attempt to unite the two Laws $n^{\circ} .6,368$ / 1976 and that of $n^{\circ} .10,409 / 2002$, previously enacted, Law $n^{\circ}$. 11,343 of August 23, 2006, reaffirming the necessary measures for prevention, care and social reintegration of individuals with some drug-related disorder through the institution of the National System of Public Policies on Drugs (SISNAD), which was also responsible for the differentiation between the figure of the dealer and the user / addict, who started to receive differentiated treatments, occupying different articles (Brasil, 2006). Also, in 2006, Decree $\mathrm{n}^{\circ} .5 .912$ determined and regulated what is the responsibility of the Executive Bodies in relation to the topic (Distrito Federal, 2006; Diel \& Gimenez, 2014).

On July 23, 2008, Law $\mathrm{n}^{\mathrm{o}}$. 11,754 was introduced, which adapts the term used to refer to public policies related to the use of narcotics. Thus, the National Anti-Drug Council was renamed the National Drug Policy Council (CONAD) and likewise the National Anti-Drug Secretariat was also renamed the National Drug Policy Secretariat (SENAD). In 2011, SENAD is once again part of the Ministry of Justice organization chart (Brazil, 2008).

More recently, Interministerial Ordinance $n^{\mathbf{o}}$. 2, of 21 December 2017, established the Interministerial Steering Committee. This Committee has among its objectives the most effective coordination of preventive actions, research and social reintegration and is composed of the Ministries of Justice, Labor, Health and Social and Agrarian Development (Brazil, 2017). In 2019, Decree $n^{\circ} .4,345$ of August 26, 2002 was revoked entirely by Decree $n^{\circ} .9,761$ of April 11, 2019. The current decree establishes that user treatment should be done through the promotion of abstinence, no longer having focus on harm reduction (Brazil, 2019).

This set of laws, ordinances and decrees made it possible to generate epidemiological, sociodemographic data on the trafficking and seizure of illicit drugs. The surveillance system consists of a continuous process of collecting, analyzing, interpreting and disseminating information in order to recommend and adopt measures to prevent and control the use and trafficking of illicit drugs nationally and internationally.

\subsection{Epidemiology}

According to the United Nations Office on Drugs and Crime (UNODOC), 5.6\% of the world population aged between 15 and 64 years used drugs at least once in 2016. The ranking of drug use this same year was led by cannabis sativa, popularly known as marijuana, having been consumed by 192 million people, followed by opioids (34 million people), amphetamines and stimulating drugs (34 million people), "ecstasy" (21 million people), opiates (19 million people) and finally cocaine, used by 18 million people worldwide (United Nations Office on Drugs and Crimes, 2018).

Despite not being used as much as other drugs, cocaine has a high additive power, leading to serious complications and even death. In the United States the number of deaths related to cocaine use has doubled in three years, with a record of 10,000 deaths in 2016, while in 2013 there were only 5,000. Despite having a lower number, when compared to the American 
continent, Asia and Africa registered the highest growth rate of cocaine seizures in 2016, reflecting the rapid spread of trafficking to less used markets (United Nations Office on Drugs and Crimes, 2018).

Colombia remains the world's largest producer and supplier of cocaine. In 2016, global cocaine manufacturing reached its highest level in history, with an estimated production. Africa and Asia are emerging as centers of drug trafficking and consumption (United Nations Office on Drugs and Crimes, 2018).

According to the III National Survey on Drug Use by the Brazilian Population, published by the Oswaldo Cruz Foundation, in 2015 the number of consumers, aged between 12 and 65 years, who used illicit drugs at least once in their lives was approximately $9.93 \%$, in which cocaine corresponds to $3.06 \%$ of use, and crack / similar to $0.91 \%$. Male gender is prevalent in both drugs, as confirmed by the literature (Fiocruz, 2017; Horta, Balbinot, Teixeira, Pinto, Oliveira \& Poletto, 2016).

In Brazil, the Notifiable Diseases Information System (SINAN) is responsible for the notification and compulsory investigation of diseases and conditions following Ordinance $n^{\circ} .4$, of September 28, 2017. Among the diseases are Drug Abuse Intoxications, which totaled approximately $14 \%$ ( $n=18,516$ cases) of records in the country in 2017, with 302 cases being notified in the Paraíba state (Information System for Notifiable Diseases, 2017).

In Paraíba, the municipality of Campina Grande stands out as a university pole, known worldwide, especially in the areas of technology and innovation. With a population of approximately 400 thousand inhabitants, it has a high percentage of schooling, reaching 97.6\% of children and adolescents aged 6 to 14 years (Brazilian Institute of Geography and Statistics, 2019).

The rapid process of industrialization in concomitance with the population agglomeration coming from the countryside cities culminated in the formation of peripheral centers, with high crime rates. Therefore, global problems such as drug trafficking and consumption, possession of weapons, robberies and thefts, among other crimes that plague the country, have become an increasingly present reality, requiring systematic actions and control through the federal police, civil and military, through public policies (Queiroz, 2008; Silva, 2014).

\subsection{Traffic x Size}

For a substance to be considered for banned use in Brazil, it must be present in Annex I of Ordinance 344 of May 12, 1998. This ordinance is constantly updated by ANVISA. For the individual to be framed for possession or trafficking in narcotic substances by Law 11.343 / 2006, the drug must be included in the list provided by this Ordinance (Brasil, 1998).

Decree $n^{\circ} .9,761$ of April 11, 2019 revokes Decree $n^{\circ} .4,345$ of August 26, 2002, making the Drug Public Policy no longer a harm reduction action, but in favor of promoting user abstinence. This action received support from the Brazilian Psychiatric Association and the Federal Council of Medicine, however, it was severely criticized by other entities such as the Federal Council of Psychology and the Anti-Asylum Struggles, which affirm the regression of this new policy (Associação Brasileira de Psicologia, 2019; Brazil, 2002; Distrito Federal, 2019; São Paulo State Anti-asylum Front, 2019; Portal Médico, 2019; Conselho Federal de Psicologia, 2019).

This decree made the legislation more lenient for the individual as a user, strengthening the need for medical treatment and unraveling the classification of the crime as possession or trafficking, having a subjective interpretation and linked to several individual, social and programmatic factors.

Individual factors are related to biological, emotional, cognitive, and attitudinal factors. Social factors are associated with cultural, social and economic aspects that can determine opportunities for access to goods and services. Programmatic factors are linked to public policies necessary for the protection of the individual, such as physical, psychological and social well-being. 
Article 28 of Law 11.343 / 2006 provides for the classification of the accused as a drug user:

Art. 28. Anyone who purchases, keeps, has in deposit, transport or brings with him, for personal consumption, drugs without authorization or in disagreement with legal or regulatory determination will be subject to the following penalties:

I - warning about the effects of drugs;

II - provision of services to the community;

III - educational measure of attendance to an educational program or course (Brasil, 2016).

Article 33 of the same law addresses the accused framed for drug trafficking:

Art. 33. Import, export, send, prepare, produce, manufacture, acquire, sell, exhibit for sale, offer, keep in deposit, transport, bring with you, store, prescribe, minister, deliver for consumption or supply drugs, even if free of charge, without authorization or in breach of legal or regulatory determination:

Penalty - imprisonment from 5 (five) to 15 (fifteen) years and payment of 500 (five hundred) to 1,500 (one thousand and five hundred) days-fine (Brazil, 2016).

In section I of chapter III with regard to the investigation, Article 50 of Law no 11.343 / 2006 deals with the materiality of the crime:

Art. 50. In the event of a flagrante delicto arrest, the judicial police authority will immediately communicate to the competent judge, sending him a copy of the drawn up record, which will be given to the Public Prosecutor's Office, within 24 (twenty-four) hours.

$\S 1$ For the purpose of drawing up the arrest record in the act and establishing the materiality of the crime, the report on the nature and quantity of the drug, signed by an official expert or, failing this, by a suitable person, is sufficient.

$\S 2$ The expert who subscribes to the report referred to in $\S 1$ of this article will not be prevented from participating in the preparation of the final report (Brazil, 2016).

Worldwide, the CRIMJUST project contributes to effectively combating organized crime in general and drug trafficking in particular along the cocaine routes in Latin America, the Caribbean and West Africa, in accordance with international legal instruments and human rights. Approximately 1,579 people participated in 61 CRIMJUST training courses in 2017, which will help strengthen law enforcement capabilities and the judiciary to detect, collect evidence, investigate, and prosecute drug trafficking cases across national borders and improve cooperation between criminal justice institutions (United Nations Office on Drugs and Crimes, 2018).

\subsection{Cocaine}

Cocaine is a drug that has been used for thousands of years, from pre-Incan and pre-Columbian peoples, until the 19th century, where its medicinal properties became popular and scientifically known through the "Form" or "Medical Guide and the Dictionary of Popular Medicine", written by the polish Pedro Luiz Napoleão Chernoviz (1812-1881) (Torcato, 2016). It is an alkaloid extracted from two species of the genus Erytroxylum, Erytroxylum novogranatense and Erytroxylum coca cultivated in different regions of the world (Freye, 2009).

Reports of cocaine use date back more than 1,200 years, when the South American natives of the Andes already used E. Coca leaves, for their stimulating properties (Pozner, Levine \& Zane, 2005). It was isolated and characterized by Albert Niemann in 1859 (Chasin, Silva \& Carvalho, 2014).

Used since pre-Incan peoples as drug therapy and in religious celebrations, cocaine in the 20th century became popular in the form of crystalline powder, being cocaine hydrochloride or cocaine sulfate, water-soluble salts, for nasal or intravenous use. Due to its high boiling point, around $187^{\circ} \mathrm{C}$, it does not volatilize and decomposes as the temperature increases (Rodrigues, 2010). 
The pharmaceutical industry's attention to this alkaloid was soon aroused, having been formulated several types of medicines, from cough syrups to anesthetics used in surgical procedures. With the frequent use of cocaine-based drugs by the population, the toxic effects and its addictive character became evident, culminating in its withdrawal as a pharmaceutical input, starting to be treated as a drug of abuse, lasting until today (Fernando \& Fuzinatto, 2012; Moreira, 2015).

The problem involving not only cocaine, but all illicit drugs, results of constant specialization and improvement of world trafficking, that is, it is useless to fight against a type of isolated drug, given that this issue must be treated as a whole since there is an interconnection between suppliers and users (Brasil, 2009).

Mentioned as one of the most complex public health problems, cocaine can be consumed in the form of cocaine hydrochloride, inhaled and injected, or smoked in the form of free base in "pipes" popularly known as crack, which presents the same symptoms, but in a more intense and less lasting way, having an even greater capacity of addition for the user (Duailibi, Ribeiro \& Laranjeira, 2008).

The table below (Table 1) demonstrates the different routes of use of cocaine, the time for the effect to begin, the purity in percentage of cocaine, the duration of the effect, the bioavailability of the substance and its metabolites, and the half life of this in the body. We can observe that the respiratory route provides the hallucinogenic effect more quickly, however, the duration is significantly shorter, generating in the user the need to consume even more drugs, as is the case of crack.

Table 1 - Pharmacokinetics and purity of cocaine in its different forms of administration.

\begin{tabular}{|c|c|c|c|c|c|}
\hline Usage Standard & Time to effect & Purity & Duration & Bioavailability & $t_{1 / 2}$ \\
\hline $\begin{array}{l}\text { Respiratory } \\
\text { (COC-base) }\end{array}$ & $10-15 s$ & $40-85 \%$ & $5 \mathrm{~min}$ & $6-32 \%$ & $38-58 \mathrm{~min}$ \\
\hline $\begin{array}{l}\text { Intravenous } \\
(\mathrm{COC} . \mathrm{HCl})\end{array}$ & $3-5 \min$ & $7-100 \%$ & $20 \min$ & $100 \%$ & $40-67 \mathrm{~min}$ \\
\hline $\begin{array}{c}\text { Intranasal } \\
(\mathrm{COC} . \mathrm{HCl})\end{array}$ & $10-15 \mathrm{~min}$ & $20-80 \%$ & $45 \min$ & $20-30 \%$ & $50-78 \mathrm{~min}$ \\
\hline $\begin{array}{c}\text { Oral } \\
(\mathrm{COC} . \mathrm{HCl})\end{array}$ & $30 \mathrm{~min}$ & $20-80 \%$ & $50 \mathrm{~min}$ & $20-30 \%$ & - \\
\hline
\end{tabular}

Source: Chasin, Silva e Carvalho (2014).

Cocaine goes through an extensive production process, from plantations to Erytroxylum even the traffic on the streets. The dried leaves go through an extractive process of maceration with organic solvent or acid solution, from which the base paste with high cocaine content is obtained, used as raw material to manufacture the forms of the commercialized drug. Approximately 100 kilograms of coca leaves are needed to make 800 grams of cocaine hydrochloride. Cocaine hydrochloride is obtained from the base paste (Chasin, Silva \& Carvalho, 2014).

Due to the physical-chemical impossibility (low volatility), traffickers and users started to carry out tests by means of chemical reactions aiming at the volatilization of the drug, and thus cocaine appeared in the form of free base, popularly known as freebasing, crack, merla and bazuco, among other denominations around the world (Oliveira \& Nappo, 2008)

The crack It is obtained by dissolving Cocaine Hydrochloride (COC.HCL) in water and adding alkalizing agents, such as sodium bicarbonate or sodium hydroxide, followed by heating and cooling the mixture. The name crack came up in the United States, refers to an onomatopoeic expression that resembles the sound of crackling due to the heating of the drug due to the presence of sodium chloride, an impurity that appeared in the process of converting cocaine to crack (Chasin, Silva \& Carvalho, 2014). 
The route of consumption of the drug is a determining factor in the rate of absorption and, consequently, in the plasma peak and bioavailability. The two most used routes are the "sniffed" intranasal using cocaine hydrochloride and the "smoked" respiratory tract using the free base. We still have the oral and intravenous routes of less use (Boghdadi \& Henning, 1997; Mosquera \& Menéndez, 2005).

Through the pulmonary alveoli, the smoked form has the highest absorption speed, with a faster plasma peak and a more intense effect, however of shorter duration, followed by the intravenous, respiratory and finally the oral route (CrespoFernandez \& Rodríguez, 2007). Table 1 shows the pharmacokinetic variables of the different patterns of use as well as their purity in relation to the cocaine content.

\subsection{Forensic Aspect}

Forensic Toxicology is an area oftoxicology that uses fundamentals of analytical chemistry for legal purposes, aiming to obtain material evidence for the Justice. In addition to researching substances in biological materials post-mortem or in living individuals, chemical expertise is also responsible for detecting the composition of samples suspected to belong to Ordinance $\mathrm{n}^{\circ} .344$, which deals with substances for illegal commercialization and use. In Brazil, these analyzes are performed basically in Laboratories of the Institutes of Criminalistics (ICs) and in the Legal Medical Institutes (IMLs) belonging to the State Security Secretariats.

In Paraíba, the Scientific Police Institute (IPC) is divided into four main nuclei responsible for different criminal analyzes. The Nucleus of Medicine and Legal Dentistry (NUMOL), responsible for investigating cases of violent death. The Criminalistics Nucleus (NUCRIM), responsible for the expertise of documents, audios, images, computing, ballistics, papiloscopy and vehicular identification. The Nucleus of Forensic Laboratories (NULF), responsible for toxicological analyzes on biological samples or not, DNA-forensics and physical-chemical analyzes, and the Nucleus for Civil and Criminal Identification (NUICC) (Scientific Police, 2018).

In order to comply with the requirements of Law $\mathrm{n}^{\circ} .11,343$ of August 23, 2006, it is necessary to obtain the materiality of the crime through two mandatory tests, the preliminary test and the definitive test. According to the recommendations of the Scientific Working Group for the Analysis of Seized Drugs there is a classification of analytical techniques in 3 groups, according to their sensitivity and specificity (Chart 1). Category A contains the most selective techniques and category $\mathrm{C}$ the least selective. According to the recommendations, for the analysis of crude drugs to be validated, it must make use of at least one technique $\mathrm{A}$ and another from any of the groups (A, B or C). If the laboratory does not have an apparatus for carrying out standard A tests, at least three techniques are required, two of which are category $\mathrm{B}$ (Scientific Working Group for the Analysis of Seized Drugs, 2014).

For the detection of the presence of cocaine through the rapid test, two techniques are used: Test with the Mayer Reagent and the Scott Test, with modified cobalt thiocyanate reagent. Mayer's reagent is effective for identifying plant alkaloids. Cocaine, being in that chemical group, reacts to form an immediate turbidity of the medium. However, this test has low selectivity, as it reacts positively to other alkaloids such as lidocaine and ecstasy (Bacchi, 2001; Passagli, 2013). 
Chart 1 - Classification of analytical techniques according to their performance by the Scientific Working Group for the Analysis of Seized Drugs.

\begin{tabular}{|c|c|c|}
\hline \multicolumn{2}{|c|}{ Analytical Techniques Categories } \\
\hline THE & B & Ç \\
\hline Infrared spectroscopy & Capillary electrophoresis & Colorimetric tests \\
\hline Mass spectrometry & Gas chromatography & Fluorescence spectroscopy \\
\hline Nuclear magnetic resonance & Ion mobility spectrometry & Immunoassay \\
\hline Raman spectroscopy & Liquid chromatography & Fusion point \\
\hline X-ray diffraction & Thin layer chromatography & Ultraviolet spectroscopy \\
\hline & Micro and macroscopic analysis $*$ & \\
\hline
\end{tabular}

* only for Cannabis sativa. Source: Scientific Working Group for the Analysis of Seized Drugs (2014).

The Modified Scott test indicates the presence of cocaine in unknown samples, it consists of a solution of cobalt thiocyanate in an acid medium that in contact with samples containing cocaine changes its color from pink to blue. This analysis is widely used as a quick or preliminary test, of great value for the arrest in flagrante offense of the accused of carrying illicit drugs. However, it is mandatory to carry out the definitive test using more specific and robust analytical methods, for final proof of the substance such as cocaine (Passagli, 2013).

For the definitive test, depending on the sample in question, there are several techniques used, such as HighPerformance Liquid Chromatography (HPLC), Mass Spectrometry, Gas Chromatography and usually, for proof of cocaine, Thin Layer Chromatography is used (CCD). This test consists of the application of a cocaine standard and the sample to be analyzed on a thin chromatography plate, followed by elution of the plate in a mobile phase of chloroform / acetone $75 / 25 \mathrm{ml}$ with $0.4 \mathrm{ml}$ of ammonium hydroxide, after complete elution is done in the chapel. Dragendorff's solution (potassium bismuth iodide) is sprayed to reveal the analytical runs, thus allowing the visualization of the retention factors and consequent proof of the presence of cocaine (Lopes, Gabriel \& Bareta, 2006).

All physical evidence must follow a Chain of Custody, which is the chronological documentation that records all the legal transit of the sample collected, thus ensuring the veracity of the evidence.

"It is used to maintain and document the chronological history of the evidence1, to track the possession and handling of the sample from the preparation of the collection container, collection, transportation, receipt, storage and analysis, therefore, it refers to the ongoing time in which the sample is being handled and includes all persons handling it. This terminology has been used legally to guarantee the identity and integrity of the sample, in all stages of the process." (Lopes, Gabriel \& Bareta, 2006).

\subsection{Epidemiology and Public Health}

Aiming to create a relationship between the facts that occurred and the individuals affected, there is the use of epidemiology in health. From the tracking of diseases such as cholera and AIDS, to the use in criminal analyzes, as proposed here, the association of sociodemographic, statistical and cartographic data contributes to the knowledge of the problem in all its aspects, making possible the geographical delimitation of a population that would be more susceptible to targeted and effective preventive action, indicating the risks, the speed of dissemination of the problem, the priorities of the intervention and mainly, formulating an explanation for the event of the public health problem with scientific basis (Hino, Scatena Villa, Midori Sassaki, Nogueira \& Santos, 2006). 
Thus, according to Carvalho et al. 2007, the study of the geographic distribution of diseases and conditions and their relationship with socioenvironmental factors constitutes what we call Geographic Epidemiology, which has been constituted in the field of application and development of new methods of analysis.

In Brazil, the problem of drugs is the subject of discussions in various spheres of Public Policy. Attempts to remedy or control the disorder are repeated. Despite the severity, there are few studies that address this issue as a Public Health problem using the Geographic Information System (GIS) combined with spatial analysis.

Historically, the most traditional example of using GIS is the cholera map made in the city of London between 1850 and 1860 by the English physician John Snow. During the cholera epidemic, he realized that the city of London was supplied by two companies: the Lamberth Company and the Southwark and Vauxhall Company. The first received water from the Thames River, located before the municipal sewer, while the second captured water after that point. From the cholera map, it was observed that of the 10,000 houses supplied by the Lamberth Company, 37 deaths occurred, and in the same number of houses supplied by the Southwark and Vauxhall Company, 315 deaths occurred. The map showed the distribution of cholera deaths, presented a spatial pattern of deaths and an association between water supply points and cholera.

Thus, according to Carvalho et al., 2007, the study of the geographic distribution of diseases and conditions and their relationship with socio-environmental factors constitutes the object that we call Geographic Epidemiology, which has been constituted in the field of application and development of new methods of analysis.

Geoprocessing consists of georeferencing data through computer programs that allow the use of maps, topographic maps and plans. When associated with previously collected events, they provide a signal of the risks that the population is exposed to, as well as monitoring the dissemination of this problem (Skaba, Carvalho, Barcellos \& Martins, 2004).

There are two types of data that can be used in georeferencing. Point Analysis and Analysis of Geographic Charts. Point Analysis, which is the simplest type, as it relates the distribution of the event's coordinates with any other variable, noting that the location is random, will be the target of statistical analysis. The Analysis from Geographic Areas, on the other hand, has defined limits, usually political-administrative divisions, such as the district where it occurs, the health district or the State, for example. It is important to remember that geographic differentiation decreases with the increase in the size of the analyzed area and its respective population. This happens due to socioeconomic differences in a given municipality or community (Carvalho, Cruz \& Souza, 2007).

Thematic maps are powerful instruments for the spatial analysis of the risk of a specific disease, condition or event, with the objective of describing and allowing visualization of the spatial distribution of the event, suggesting the local determinants and unknown etiological factors that may originate the formulation of hypotheses and point out associations between the event and its determinants.

In Brazil, little is known about the spatial distribution of illicit drug seizures in urban and rural areas. Based on this premise, the present project aims to trace the epidemiological profile of individuals who were seized carrying quantities of cocaine in the municipality of Campina Grande, based on forensic analysis.

\section{Methodology}

This was an aggregate, observational (investigator's position), cross-sectional and ecological study based on sociodemographic data and illicit drug seizures. The option for epidemiological studies of the ecological type may be logically adequate for the understanding of risk variation among different population groups. An important approach from an ecological point of view is to consider space as a multidimensional factor of stratification of populations, which allows to visualize spatially, in an articulated way, the distributions of drug seizures and risk. For the study of spatial analysis, data from 
geographic areas with defined boundaries, usually political-administrative divisions, can be used. Our study chose the area data, more specifically the neighborhood variable (Carvalho, Cruz, \& Souza, 2007).

The data were taken from the reports filed by the Campina Grande Forensic Laboratory Nucleus (NULF-CG / IPC) and the files at the Narcotic Court of the District of Campina Grande located at the Afonso Campos Forum.

\subsection{Research and Population Location}

The geographical area studied was the municipality of Campina Grande (PB), located in the mesoregion agreste of Paraíba. This municipality has 594,182 $\mathrm{km}^{2}$ of land area; eight health districts (six in the urban area and two in the rural area) and 52 neighborhoods. According to the census conducted by the Brazilian Institute of Geography and Statistics (IBGE), in 2010 its population was composed of 385,213 inhabitants and its demographic density is 648.31 inhabitants per square kilometer (IBGE, 2010). The municipality in question is a University and Technological Center that has great political and economic influence over more than 60 surrounding municipalities.

The population studied included the seizures of illicit drugs recorded in 2017 for the city of Campina Grande, in the Finding and Definitive Reports carried out by the Forensic Laboratory Nucleus of Campina Grande (NULF-CG / IPC) and in the lawsuits filed at the Narcotics Court of the District of Campina Grande.

The NULF is made up of laboratories that are responsible for the Finding and Definitive Reports, according to the requirements of Law n ${ }^{\circ} 11.343$ of August 23, 2006. These laboratories belong to the Scientific Police Institute of the State of Paraíba (IPC-PB). The IPC is the Official Department of expertise of the State of Paraíba. The experts carry out their duties in response to requests for expert opinions from delegates, prosecutors and judges, relating to police investigations and criminal proceedings.

All reports with satisfactory information on the socioeconomic profile of the individual indicted for illegal possession of cocaine in 2017, according to Law $\mathrm{n}^{\circ} .11,343$ of 2006, whose seizures occurred in the municipality of Campina Grande were included in the research.

The variables used for the study were related to seasonality (Monthly Distribution), to the visual characteristics of the seized drugs (white colored powder, white colored paste, white colored solid substance, yellow colored solid substance), to the sociodemographic data (gender, age group, marital status, education and situation in the job market and in relation to the neighborhoods of occurrence, this last variable was obtained from the "52 codes" available at the Statistics Department of the Science and Technology Center of Universidade Estadual da Paraíba (Table 2). 
Table 2 - Codification of neighborhoods in the municipality of Campina Grande.

\begin{tabular}{|c|c|c|c|c|c|c|c|}
\hline $\operatorname{cod}$ & NEIGHBORHOODS & cod & NEIGHBORHOODS & cod & NEIGHBORHOODS & $\operatorname{cod}$ & NEIGHBORHOODS \\
\hline 1 & MONTE CASTELO & 15 & MONTE SANTO & 28 & RAMADINHA & 40 & PALMEIRA \\
\hline 2 & CASTELO BRANCO & 16 & BELA VISTA & 29 & PRESIDENTE MÉDICE & 41 & PRATA \\
\hline 3 & MIRANTE & 17 & SANTA ROSA & 30 & SANTA CRUZ & 42 & QUARENTA \\
\hline 4 & CATOLÉ & 18 & CENTENÁRIO & 31 & PEDREGAL & 43 & LIBERDADE \\
\hline 5 & JARDIM TAVARES & 19 & CRUZEIRO & 32 & TAMBOR & 44 & LOUZEIRO \\
\hline 6 & JOSÉ PINHEIRO & 20 & & 33 & ESTAÇÃO VELHA & 45 & NAÇÕES \\
\hline 7 & SANDRA CAVALCANTE & 21 & UNIVERSITÁRIO & 34 & JARDIM CONTINENTAL & 46 & ITARARÉ \\
\hline 8 & VILA CABRAL & 22 & DISTRITO INDUSTRIAL & 35 & CONCEIÇÃO & 47 & LAURITZEN \\
\hline 9 & & 23 & NOVO BODOCONGÓ & 36 & ALTO BRANCO & 48 & SANTO ANTÔNIO \\
\hline 10 & TRÊS IRMÃS & 24 & BODOCONGÓ & 37 & CENTRO & 49 & NOVA BRASÍLIA \\
\hline 11 & SERROTÃO & 25 & ACÁCIO FIGUEIREDO & 38 & SÃO JOSÉ & 50 & \\
\hline 12 & JEREMIAS & 26 & MALVINAS & 39 & JARDIM PAULISTANO & 51 & VELAME \\
\hline 13 & ARAXÁ & 27 & DINAMÉRICA & 40 & PALMEIRA & 52 & CIDADES \\
\hline 14 & CUITÉS & & & & & & \\
\hline
\end{tabular}

Source: Own authorship.

\subsection{Data Processing and Analysis}

In data analysis, descriptive statistics was used, using simple absolute and percentage frequencies for categorical variables and organization of results in tables. Then, the chi-square adherence test was applied to verify the suitability of the probabilistic model to the research data. In addition, to verify possible associations between the variables under study, the Chisquare test and Fisher's exact test were used in cases where the expected frequencies were less than 5 (SIEGEL, 2006), considering the significance level of $5 \%(\mathrm{p}<0.05)$. The analyzes were performed with the aid of the statistical software $\mathrm{R}(\mathrm{R}$ Core Team, 2019).

Thematic maps were prepared with the aid of Excel spreadsheets and the computer programs of Geographic Information Systems Diva-Gis and Qgis. The coordinates of the apprehension points were collected according to the address contained in the expert reports using Google Maps.

\section{Results and Discussion}

In 2017, 210 cocaine seizures were recorded, of which 146 occurred in the municipality of Campina Grande, of which, only 94 presented all the data and were considered in this study (Table 2). 
Table 3 - Number of Seizures registered in the XX Narcotics Court of the District of Campina Grande, Paraíba, in the Afonso Campos Forum, in 2017.

\begin{tabular}{ccc}
\hline & $\mathrm{n}^{\text {o }}$ of Seizures & $\%$ \\
\hline TOTAL & $\mathbf{2 1 0}$ & $\mathbf{1 0 0}$ \\
Campina Grande & 146 & 69 \\
Other Municipalities & 64 & 31 \\
\hline Full Reports & $\mathbf{9 4}$ & $\mathbf{4 4}$ \\
\hline
\end{tabular}

Source: Own authorship.

During 2017, the months of September and October presented the highest number of seizures, 14 and 13, respectively. The physical form of the most common drug, broken down in the case file, was the yellowish-colored stone, popularly known as "crack". The white paste or cocaine-based paste was seized only in April. The white powder, probably COC.HCL, was the second most found (Figure 1).

Figure 1 - Distribution of the number of cocaine seizures in the municipality of Campina Grande in 2017, according to the physical characteristics of the drug and the month of seizure.

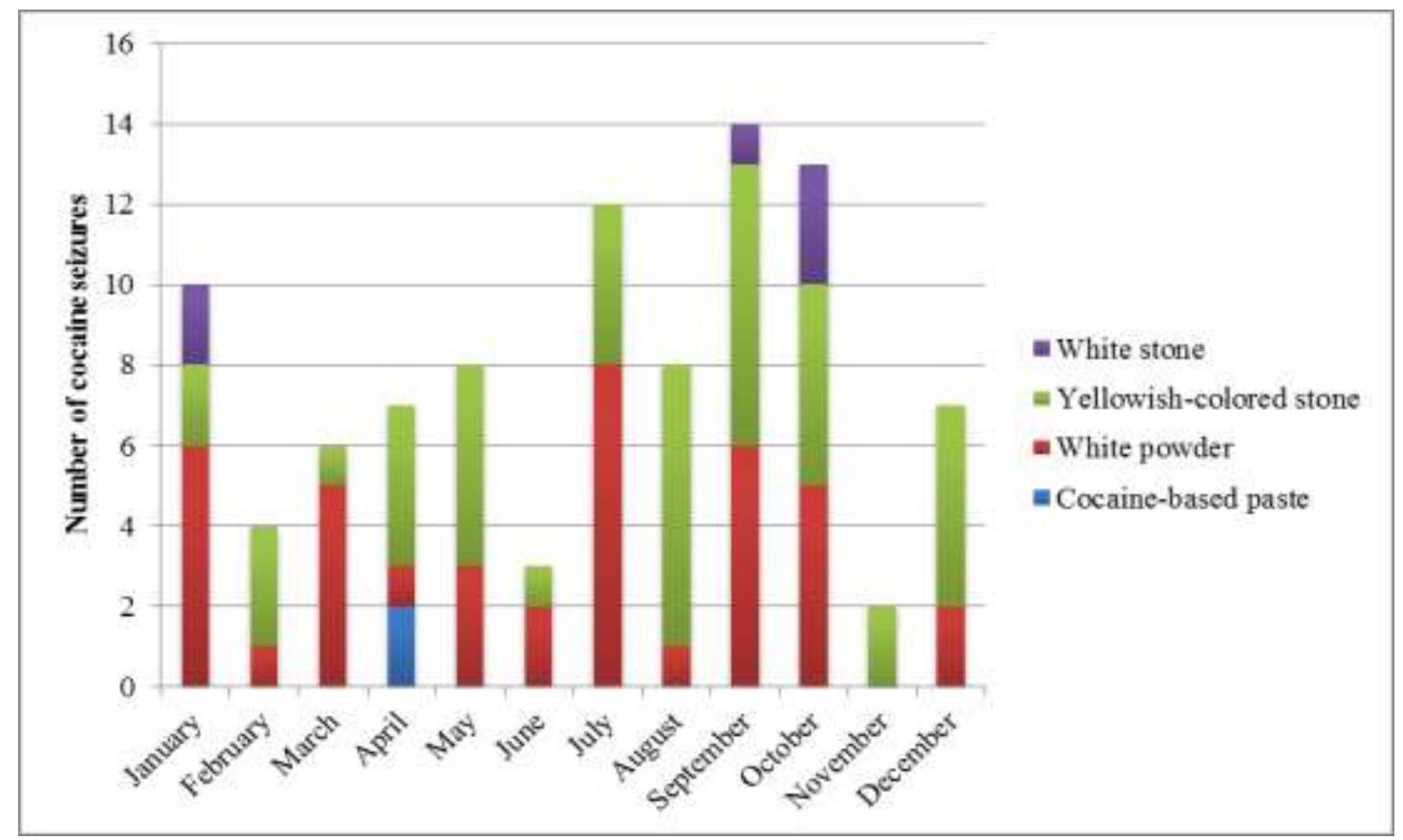

Source: Own authorship.

Analyzing the results on the physical form of cocaine most apprehended in this research, we find similarity with data published in According to the Brazilian Report on Drugs, published in 2009. In this report, there was a tendency of increase in the seizure of cocaine in Brazil, in the period of 2001 to 2007. 2007 was also the year in which the most drug seizures were recorded. Cocaine led the number of seizures in the form of crack. This increase, however, cannot be interpreted exclusively as a reflection of the increased consumption and circulation of drugs in the country, but also as a result of an increase in the quantity and effectiveness of police operations for seizing drugs (Brasil, 2009). 
There was a predominance of males with $82.98 \%$ of seizures $(\mathrm{n}=78)$. The majority were young $(60.63 \%)$, single $(59.57 \%)$, with elementary education $(84.04 \%)$ and without employment (68.09\%) (Table 4). The data found are in agreement with other studies carried out in São Paulo (SP), by Ferreira Filho et al., 2003 and Oliveira; Nappo, 2008).

Sociodemographic variables showed a significant degree of association using the Chi-square test ( $>$ >0.05). The use patterns with the highest incidence were yellowish stone (crack) for respiratory use with 46 seizures and white powder (COC.HCL), for intranasal use, corresponding to 40 seizures. Regarding the framing of the offense, $79.79 \%$ were classified as drug trafficking, according to Article 33 of theLaw n. 11,343 of August 23, 2006 (Table 3).

Table 4 - Sociodemographic profile of individuals indicted by Law nº. 11,343 of August 23, 2006, according to gender, marital status, age group, education, situation in the labor market, pattern of use and crime.

\begin{tabular}{|c|c|c|c|}
\hline Population Characteristics & $\mathbf{N}$ & $\%$ & $P$ \\
\hline \multicolumn{4}{|l|}{ Genre } \\
\hline Male & 78 & 82.98 & \multirow[t]{2}{*}{$<0.001$} \\
\hline Feminine & 16 & 17.02 & \\
\hline \multicolumn{4}{|l|}{ Marital status } \\
\hline Not married & 56 & 59.57 & \multirow[t]{3}{*}{$<0.001$} \\
\hline Married & 9 & 9.57 & \\
\hline Stable union & 29 & 30.85 & \\
\hline \multicolumn{4}{|l|}{ Age Range } \\
\hline$<18$ & 4 & 4.25 & \multirow{4}{*}{$<0.001$} \\
\hline $18-25$ & 57 & 60.63 & \\
\hline $26-35$ & 26 & 27.65 & \\
\hline$>35$ & 7 & 7.44 & \\
\hline \multicolumn{4}{|l|}{ Education } \\
\hline Elementary School & 78 & 84.04 & \multirow[t]{3}{*}{$<0.001$} \\
\hline High school & 12 & 12.77 & \\
\hline Without Instruction & 3 & 3.19 & \\
\hline \multicolumn{4}{|l|}{ Situation in the Labor Market } \\
\hline Self-employed & 9 & 9.57 & \\
\hline Unemployed & 64 & 68.09 & \\
\hline Employee & 21 & 22.34 & \\
\hline \multicolumn{4}{|l|}{ Usage Pattern } \\
\hline White Pasta & 2 & 2.13 & $<0.001$ \\
\hline White powder & 40 & 42.55 & \\
\hline Yellowish Stone & 46 & 48.94 & \\
\hline White Rock & 6 & 6.38 & \\
\hline \multicolumn{4}{|l|}{ Crime } \\
\hline Trafficking (Art. 33 - Law 11.343) & 75 & 79.79 & \\
\hline Size (Art. 28 - Law 11.343) & 19 & 20.21 & \\
\hline
\end{tabular}

Source: Own authorship.

The profile of the apprehended individual carrying cocaine in this study is in line with other research conducted nationwide, as in the cross-sectional study conducted in 2003 in the greater São Paulo by Olavo Franco Ferreira Filho, et al. 
And also, in the study carried out in São Paulo City by Lúcio Garcia de Oliveira and Solange Aparecida Nappo, 2008. Both show the profile of the cocaine user / bearer as an individual, male, with low education and no employment relationship (Ferreira Filho et al, 2003; Oliveira and Nappo, 2008).

For the evaluation of the specific variable DELIT, divided into size and traffic, the Fisher's exact test in cases where the expected frequencies were less than five, in relation to gender, education and pattern of use, with no association between variables $(\mathrm{p}<0.05)($ Table 4$)$.

In the geospatial analysis of data from the neighborhood areas of Campina Grande City, the number of seizures was divided into quartiles and distributed on a map according to the number of seizures and the neighborhood of occurrence.

Table 5 - Testand Association between Crime, Gender, Education and Standard of Use.

\begin{tabular}{ccccc}
\hline & Size & Traffic & Total & $P$ \\
\hline Genre & 18 & 60 & 78 & \\
Male & 1 & 15 & 16 & 0.236 \\
Feminine & & & & \\
Education & 19 & 60 & 79 & 0.104 \\
Elementary School & 0 & 12 & 12 & \\
High school & 0 & 3 & 3 & \\
Without Instruction & & 2 & 2 & \\
Usage Standard & 0 & 27 & 40 & \\
White Pasta & 13 & 40 & 46 & \\
White powder & 6 & 6 & 6 & \\
Yellowish Stone & 0 & & & \\
White Rock & Cot & & & \\
\hline
\end{tabular}

Source: Own authorship.

Due to the high number of neighborhoods $(\mathrm{n}=23)$, which did not obtain any records of apprehension, the division into quartiles was impaired, and the question remains whether the absence of apprehensions in these neighborhoods was due there were no crime or a failure in the notification, losing valuable information for tracking the phenomenon of cocaine trafficking and consumption in the municipality.

The neighborhoods with the highest number of seizures were: Serrotão, Ramadinha, Bodocongó, Pedregal, Araxá, Jeremias, Santa Rosa, Liberdade, Tambor, José Pinheiro, Santo Antônio, Nova Brasília and Cidades Quartil [3,15]. Of these, José Pinheiro stands out, with 15 seizures, Pedregal and Liberdade with 8 seizures and Serrotão 6 seizures (Figure 2). This high number of seizures in the first two neighborhoods is related to high crime and the consequent individual vulnerability of the community. In a survey conducted by Silva, 2014, in the municipality of Campina Grande, the neighborhoods of José Pinheiro and Pedregal were part of the two municipal sectors with the highest percentage of crime. In a study carried out by Medeiros and Fook, 2019, according to the 2010 IBGE census, José Pinheiro and Liberdade presented Very High Vulnerability. 
Figure 2 - Map of Quartiles, according to the neighborhoods of cocaine seizures, which occurred in the municipality of Campina Grande in 2017.

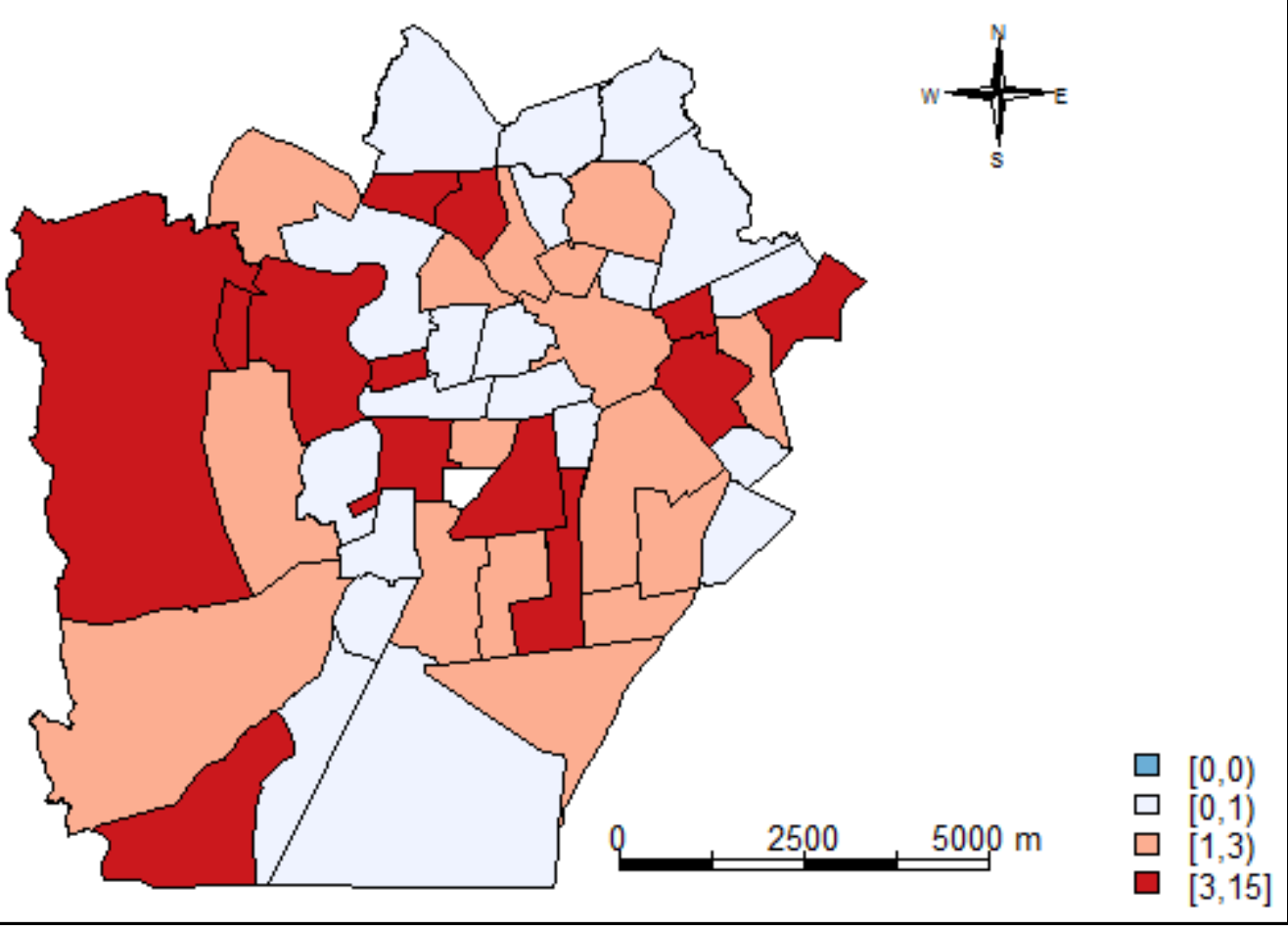

Source: Own authorship.

In a study conducted by Silva e Chao (2009) in the city of Campina Grande, specifically in the neighborhood Zé Pinheiro, it was found that despite being one of the oldest neighborhoods and with the second largest trade in the city, violence is a problem that deflates the lives of the people who live there. The gangs and organized crime groups that have occupation there threaten and make it difficult to hold cultural events and social projects, since the people feel prevented from using some public spaces due to the lack of security and because they feel threatened by the criminal organizations that command the place. Often, spaces such as squares and sports courts become trafficking points in the hands of criminals, preventing the free access of people and residents.

According to the Moran Scattering Graph (Figure 3), analytically in 2017, it can be seen that there is no cause and effect relationship between the neighborhoods, that is, the number of cocaine seizures in a neighborhood $\mathrm{X}$ does not affect the distribution in surrounding neighborhoods, that is, seizures happen at random. This data was confirmed by the Spatial Autocorrelation Test or General Moran Index (Table 3) and by the Local Moran Index, according to each neighborhood individually (Table 4). These tests showed no significant correlation between neighborhoods.

Table 6 - Spatial Autocorrelation Test.

\begin{tabular}{|c|c|c|c|c|}
\hline \multirow{2}{*}{ Covariables } & \multicolumn{4}{|c|}{ Statistics } \\
\cline { 2 - 5 } & Moran Global & $\boldsymbol{P}$-value & Geary & $\boldsymbol{P}$-value \\
\hline Drug & -0.0288 & 0.541 & 0.9557 & 0.3565 \\
\hline
\end{tabular}

Source: Own authorship. 
Figure 3 - Moran Scattering Diagram for cocaine seizure cases, according to the neighborhoods of the municipality of Campina Grande in 2017.

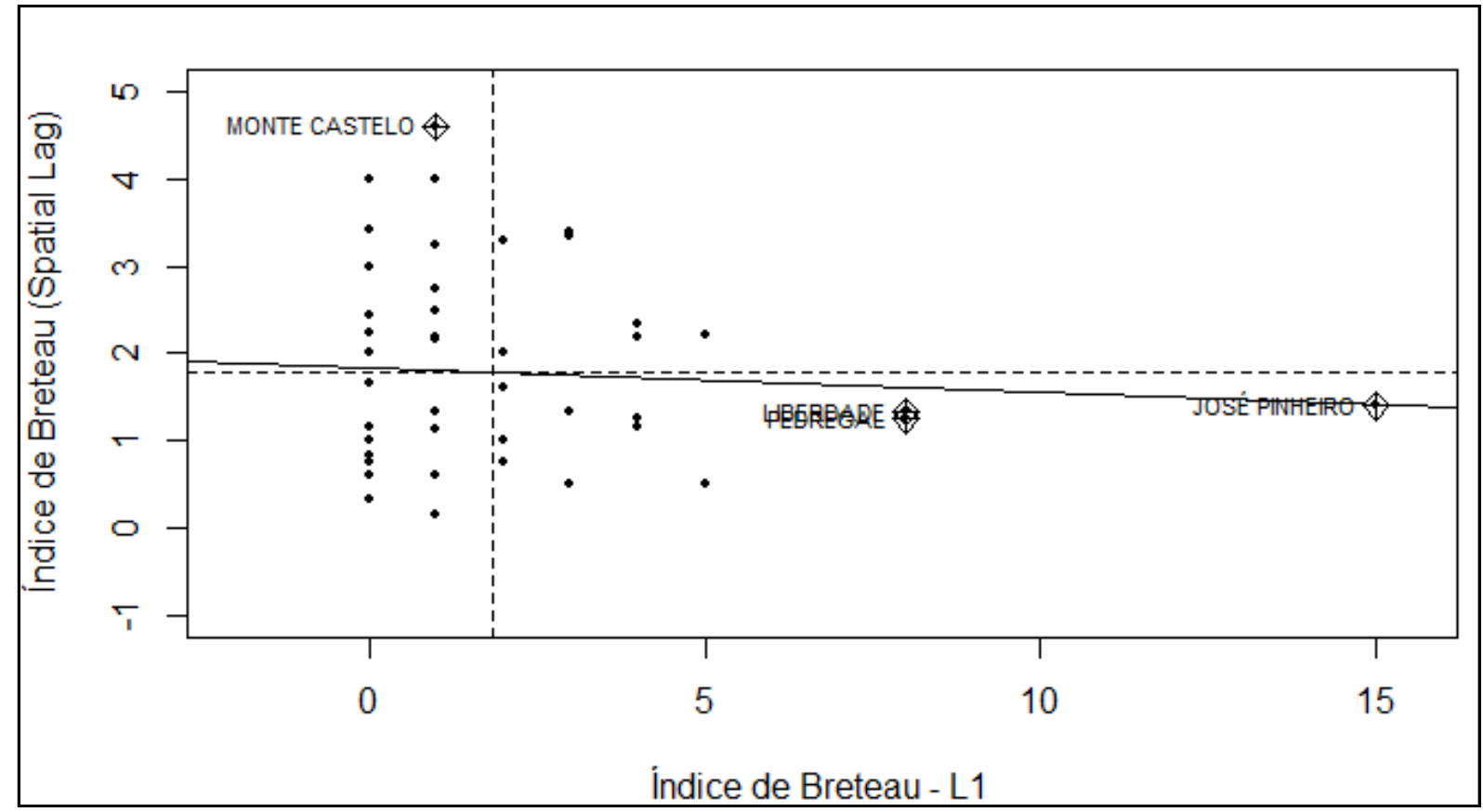

Source: Own authorship.

Table 7 - Local Moran Index by neighborhood.

\begin{tabular}{|c|c|c|c|c|c|c|c|}
\hline ID & Pr (z> 0) & ID & Pr $(\mathbf{z}>\mathbf{0})$ & ID & Pr $(\mathbf{z}>\mathbf{0})$ & ID & Pr $(\mathbf{z}>\mathbf{0})$ \\
\hline $\mathbf{1}$ & 0.77 & $\mathbf{1 5}$ & 0.5 & $\mathbf{2 8}$ & 0.31 & $\mathbf{4 0}$ & 0.38 \\
\hline $\mathbf{2}$ & 0.57 & $\mathbf{1 6}$ & 0.52 & $\mathbf{2 9}$ & 0.2 & $\mathbf{4 1}$ & 0.2 \\
\hline $\mathbf{3}$ & 0.91 & $\mathbf{1 7}$ & 0.57 & $\mathbf{3 0}$ & 0.3 & $\mathbf{4 2}$ & 0.57 \\
\hline $\mathbf{4}$ & 0.43 & $\mathbf{1 8}$ & 0.65 & $\mathbf{3 1}$ & 0.86 & $\mathbf{4 3}$ & 0.87 \\
\hline $\mathbf{5}$ & 0.22 & $\mathbf{1 9}$ & 0.47 & $\mathbf{3 2}$ & 0.32 & $\mathbf{4 4}$ & 0.25 \\
\hline $\mathbf{6}$ & 0.97 & $\mathbf{2 1}$ & 0.88 & $\mathbf{3 3}$ & 0.76 & $\mathbf{4 5}$ & 0.22 \\
\hline $\mathbf{7}$ & 0.5 & $\mathbf{2 2}$ & 0.48 & $\mathbf{3 4}$ & 0.26 & $\mathbf{4 6}$ & 0.55 \\
\hline $\mathbf{8}$ & 0.36 & $\mathbf{2 3}$ & 0.62 & $\mathbf{3 5}$ & 0.34 & $\mathbf{4 7}$ & 0.25 \\
\hline $\mathbf{1 0}$ & 0.41 & $\mathbf{2 4}$ & 0.25 & $\mathbf{3 6}$ & 0.27 & $\mathbf{4 8}$ & 0.25 \\
\hline $\mathbf{1 1}$ & 0.37 & $\mathbf{2 5}$ & 0.3 & $\mathbf{3 7}$ & 0.53 & $\mathbf{4 9}$ & 0.81 \\
\hline $\mathbf{1 2}$ & 0.69 & $\mathbf{2 6}$ & 0.52 & $\mathbf{3 8}$ & 0.43 & $\mathbf{5 1}$ & 0.3 \\
\hline $\mathbf{1 3}$ & 0.63 & $\mathbf{2 7}$ & 0.57 & $\mathbf{3 9}$ & 0.7 & $\mathbf{5 2}$ & 0.62 \\
\hline $\mathbf{1 4}$ & 0.57 & & & & & & \\
\hline
\end{tabular}

Source: Own authorship.

The analysis of the geoprocessing of cartographic points is demonstrated in the Points map (Figure 4). It is observed through this map, once again, that there is a randomness present in these seizures, highlighting the cluster present in district 01 , corresponding to the locality of the José Pinheiro neighborhood, which accounted for the largest number of cocaine seizures this year $(n=15)$. 
Figure 4 - Point Map of cocaine seizures, distributed according to the health districts and their respective neighborhoods, in the municipality of Campina Grande, using geographic coordinates in 2017.

HEALTH DISTRICT I
Monte Castelo
José Pinheiro
Nova Brasilia
Santo Antônio
Castelo Branco
Mirante
Jardim Tavares
Centro
HEALTH DISTRICT 2
Serrotão
Bodocongó
Pedregal
Centenário
Bela Vista
Bairro Universitário
Novo Bodocongó
Prata
HEALTH DISTRICT 3
Monte Santo
Palmeira
Jeremias
Araxá
Conceição
Nações
Jardim Continental
Cuités
Alto Branco
Louzeiros
Lauritzen

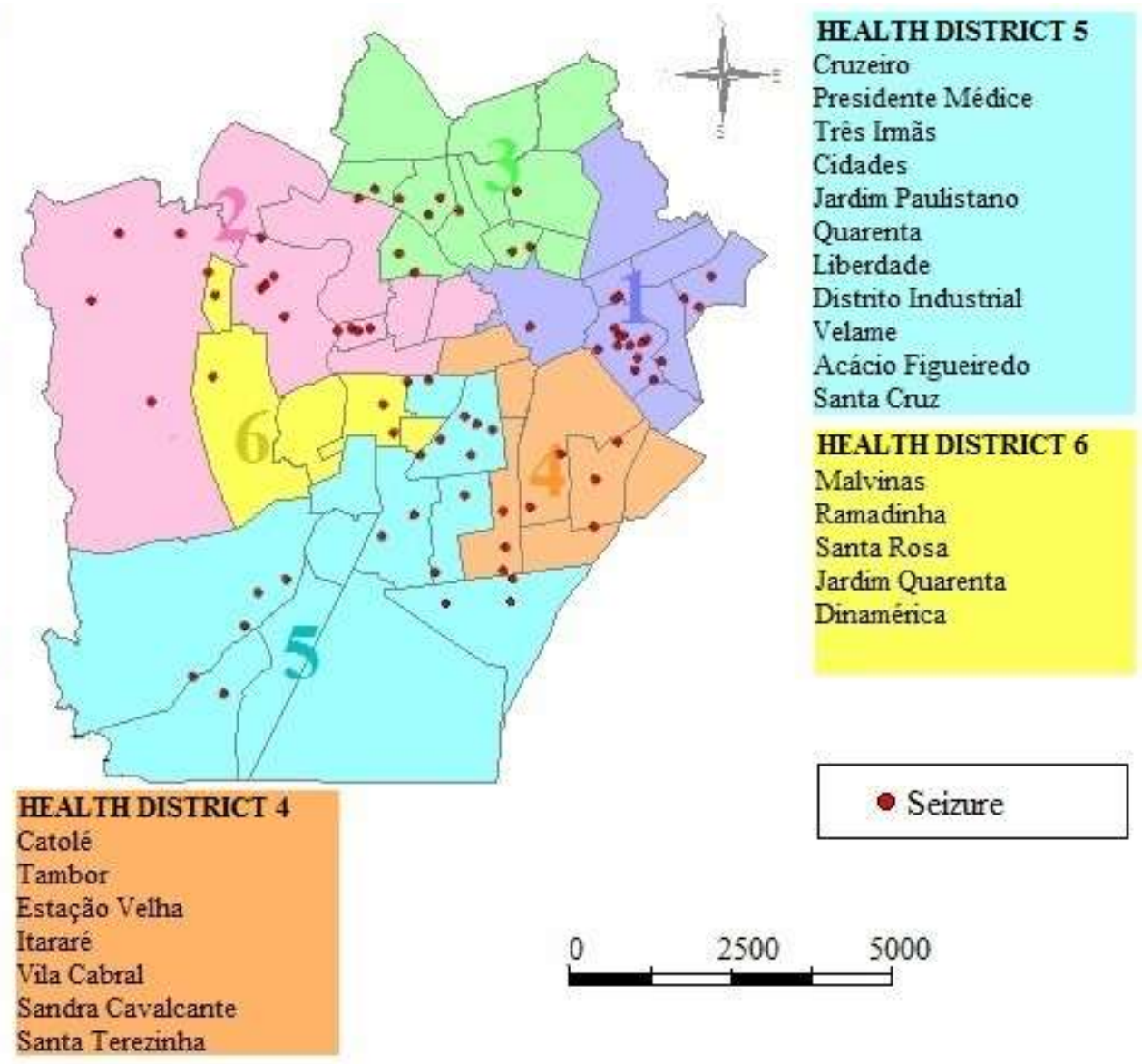

Source: Own authorship.

\section{Final Considerations}

In this study, it was possible to establish the profile of the individual cocaine user or dealer in the municipality of Campina Grande as being predominantly young male, single, with elementary education and unemployed. Beyond the profile of the seized drug and its predominant place of seizure, we have cocaine in its yellowish stone form (crack) and white colored powder as the most seized and the neighborhoods that presented the greatest quantity of cocaine seizures in Campina Grande in 2017 were José Pinheiro and Pedregal. Marginalized neighborhoods with high personal vulnerability, however, it was proved by the Autocorrelation Test, these neighborhoods do not influence others in the surrounding area, so the cocaine seizures that occurred in 2017 in the municipality of Campina Grande occurred at random.

There was a deficit in the registration of sociodemographic data in the initial reports of the individual was caught with possession of narcotics, making it difficult to report, track and determine a profile of drug use in the city of Campina Grande. The mapping of these seizures can help in strengthening of the national drug policy, especially in what is established in Law 11.343 of August 2006, which deals with the repression of unauthorized drug production and trafficking, in addition to the sectorial Public Policies of the Executive Branch of the Union, Federal District, States and Municipalities.

\section{References}

Associação Brasileira de Psicologia (1966-2019). Presidente da República assina decreto que aprova a Nova Política Nacional sobre Drogas. https://www.abp.org.br/post/aprovacao-nova-pnad 
Bacchi, E. M. Alcalóides Indólicos. (2001). In: Simoes, C, M, O., Schenkel, E, P., Grace, G., Mello, J, C, P., Mentz, L, A., \& Pedro, P, R. Farmacognosia: da planta ao medicamento. (3th ed.): editora da Universidade UFRGS.

Brasil (2008). Acresce, altera e revoga dispositivos da Lei $n^{\circ}$ 10.683, de 28 de maio de 2003, cria a Secretaria de Assuntos Estratégicos da Presidência da República, cria cargos em comissão; revoga dispositivos das Leis $n^{o}$ s 10.869, de 13 de maio de 2004, e 11.204, de 5 de dezembro de 2005; e dá outras providências. Lei n. 11.754, de 23 de Julho de 2008. Diário Oficial da União, seção 1, p. 1.

Brasil (2009). Presidência da República. Secretaria Nacional de Políticas sobre Drogas. Relatório brasileiro sobre drogas / Secretaria Nacional de Políticas sobre Drogas; IME USP; organizadores Paulina do Carmo Arruda Vieira Duarte, Vladimir de Andrade Stempliuk e Lúcia Pereira Barroso. - Brasília: SENAD, $\mathrm{p} 48$.

Brasil (2019). A Secretaria Nacional de Políticas Sobre Drogas - SENAD. Ministério da Justiça e Segurança Pública. https://www.justica.gov.br/suaprotecao/politicas-sobre-drogas/conheca-a-senad

Brasil (1986). Cria o Fundo de Prevenção, Recuperação e de Combate às Drogas de Abuso, dispõe sobre os bens apreendidos a adquiridos com produtos de tráfico ilícito de drogas ou atividades correlatas, e dá outras providências. Lei n. 7.560, de 19 de dezembro de 1986. Coleção de Leis do Brasil, 7, 123.

Brasil (2002). Dispõe sobre a prevenção, o tratamento, a fiscalização, o controle e a repressão à produção, ao uso e ao tráfico ilícitos de produtos, substâncias ou drogas ilícitas que causem dependência física ou psíquica, assim elencados pelo Ministério da Saúde, e dá outras providências. Lei n. 10.409, de 11 de Janeiro de 2002. Diário Oficial da União, seção 1, p. 1.

Brasil (1976). Dispõe sobre medidas de prevenção e repressão ao tráfico ilícito e uso indevido de substâncias entorpecentes ou que determinem dependência física ou psíquica, e dá outras providências. Lei n. 6.368, de 21 de outubro de 1976. Coleção de Leis do Brasil, Brasília, 7, 90.

Brasil (2006). Institui o Sistema Nacional de Políticas Públicas sobre Drogas - Sisnad; prescreve medidas para prevenção do uso indevido, atenção e reinserção social de usuários e dependentes de drogas; estabelece normas para repressão à produção não autorizada e ao tráfico ilícito de drogas; define crimes e dá outras providências. Lei n. 11.343, de 23 de Agosto de 2006. Diário Oficial da União, seção 1, p. 2.

Brasil (2015). Ministério da Saúde. Secretaria de Atenção à Saúde. Departamento de Ações Programáticas Estratégicas. Guia estratégico para o cuidado de pessoas com necessidades relacionadas ao consumo de álcool e outras drogas: Guia AD / Ministério da Saúde, Secretaria de Atenção à Saúde, Departamento de Ações Programáticas Estratégicas. Ministério da Saúde, Brasília, p. 100, ed. 1.

Brasil (12 mai. 1998.). Ministério da Saúde. Secretaria de Vigilância em Saúde. Portaria nº 344, de 12 de Maio de 1998. Aprova o Regulamento Técnico sobre substâncias e medicamentos sujeitos a controle especial. Diário Oficial da União, Brasília, DF.

Brasil (2017). Secretaria Nacional de Políticas sobre Drogas; Duarte, V. A. C. P and Formigoni, S. O. L. M. O uso de substâncias psicoativas no Brasil. Módulo. 11, 146, Brasília: Secretaria Nacional de Políticas sobre Drogas.

Brasil (2009). Secretaria Nacional de Políticas Sobre Drogas. Relatório Brasileiro sobre Drogas: SENAD.

Boghdadi, S. M., \& Henning, J. R. (1997). Cocaine: pathophysiology and clinical toxicology. Heart \& Lung. 26(6), 466-483.

Carvalho, J. C. (2011). Uma história política da criminalização das Drogas no brasil; a construção de uma Política nacional. Núcleo de Estudos Interdisciplinares sobre Psicoativos. Rio de Janeiro.

Carvalho, M. S., Cruz, O. G., \& Souza, W.O. (2007). Conceitos Básicos em Análise de Dados Espaciais em Saúde. In: Brasil. Ministério da Saúde. Secretaria de Vigilância em Saúde. Fundação Oswaldo Cruz. Introdução à Estatística Espacial para a Saúde Pública / Ministério da Saúde, Fundação Oswaldo Cruz (p. 15-27). Simone M. Santos, Wayner V. Souza, organizadores - Brasília: Ministério da Saúde.

Chasin, M. A. A., Silva, S. E., \& Carvalho, M, V. (2014). Estimulantes do Sistema Nervoso Central. In: Oga, S., Camargo, A. M. M., \& Batistuzzo, O. A. J. Fundamentos de Toxicologia. (p. 364-383.) (4th ed.): Atheneu Editora.

Conselho Federal De Psicologia. SAF Sul (1973-2019). Desenvolvido pelo Setor de Administração Federal Sul. Governo Federal decreta fim da política de Redução de Danos. https://site.cfp.org.br/governo-federal-decreta-fim-da-politica-de-reducao-de-danos/

Crespo-fernandez, J. A., \& Armida Rodriguez, C. (2007). Bases neuroanatómicas, neurobiológicas y del aprendizaje de la conducta de adicción a la cocaína. Rev. Latinoam. Psicol., 39(1), 83-107.

Diel, S. F. A., \& Gimenez, C. P. C. (2014). A Política Criminal de Drogas como Expressão Máxima do Controle Social e Punitivismo do Sistema Penal Contemporâneo. Anais do Salão de Pesquisa da Faculdade EST, São Leopoldo, 13, 17-30.

Distrito Federal (2002). Decreto n. 4.345, de 26 de Agosto de 2002. Institui a Política Nacional Antidrogas e dá outras providências. Diário Oficial da União, seção 1, p. 3.

Distrito Federal (2006). Decreto n. 5.912, de 27 de Setembro de 2006. Regulamenta a Lei $n^{\circ} 11.343$, de 23 de agosto de 2006, que trata das políticas públicas sobre drogas e da instituição do Sistema Nacional de Políticas Públicas sobre Drogas - SISNAD, e dá outras providências. Diário Oficial da União, seção 1, p. 8.

Distrito Federal (1980). Decreto n. 85.110, de 2 de Setembro de 1980. Institui o Sistema Nacional de Prevenção, Fiscalização e Repressão de Entorpecentes e dá outras providências. Coleção de Leis do Brasil, 6, 279.

Distrito Federal (2019). Decreto n. 9.761, de 11 de Abril de 2019. Aprova a Política Nacional sobre Drogas. Diário Oficial da União, seção. Extra-A, p. 7.

Duailibi, L. B., Ribeiro, M., \& Laranjeira. R. (2008). Profile of cocaine and crack users in Brazil. Cad. Saúde Pública, 24(4), 545-557. 
Fernando, V. R., \& Fuzinato, A. M. (2012). Drogas: proibição, criminalização da pobreza e mídia. In, Congresso Internacional de Direito e Contemporaneidade, $1^{\text {a }}$ Edição, 2012- Santa Maria, Anais - Sistema Penal e Mídia. p. 1-11.

Ferreira Filho, O. F., Turchi, M. D., Laranjeira, R., \& Castelo, A. (2003). Perfil sociodemográfico e de padrões de uso entre dependentes de cocaína hospitalizados. Rev. Saúde Pública, 37(6), 751-759.

Fundação Oswaldo Cruz (2017). III Levantamento Nacional sobre o Uso de Drogas pela População Brasileira.

Frente Estadual Antimanicomial de São Paulo (2010-2019). Desenvolvido pela Frente Estadual Antimanicomial de São Paulo. Manifesto de Repúdio à Nota Técnica $n^{o}$ 11/19 MS e em Defesa da Luta Antimanicomial, do SUS e da Democracia! https://antimanicomialsp.wordpress.com/2019/02/14/manifesto-derepudio-a-nota-tecnica-no-11-19-ms-e-em-defesa-da-luta-antimanicomial-do-sus-e-da-democracia/

Freye, E. (2009). How It All Started with Cocaine. In: Freye, E. Pharmacology and Abuse of Cocaine, Amphetamines, Ecstasy and Related Designer Drugs. New York, Springer, 9-104.

Hino, P., Scatena Villa, T. C., Midori Sassaki, C., Nogueira, J. A., \& Santos, C. B. (2006). Geoprocessamento aplicado à área da saúde. Rev. Latino-Am. Enfermagem, 14(6), 939-943.

Horta, R. L., Balbinot, A. D., Teixeira, V. A., Pinto, R. O., Oliveira, G. O., \& Poletto, S. (2016). Padrão de uso e possibilidade de cessação do consumo do crack: estudo transversal. Estudos de Psicologia (Campinas), 33(2), 325-334.

IBGE - Instituto Brasileiro De Geografia E Estatística (2019). Panorama Cidade de Campina Grande. Campina Grande. Retrieved from https://cidades.ibge.gov.br/brasil/pb/campina-grande/panorama

Lopes, J. L. C. (2006). Cromatografia em camada delgada. Capitulo 3. In: Collins, C. H., Braga, G. L., \& Bonato, P. S. Fundamentos de cromatografia: Editora Unicamp.

Lopes, M., Gabriel, M. M., \& Bareta, G. M. S. (2006). Cadeia de custódia: uma abordagem preliminar. Visão Acadêmica, 7(1).

Medeiros, S. C. N., \& Fook, S. M. L. (2019). Drogas ilícitas e sua relação com a vulnerabilidade social: uma abordagem espacial. Dissertação (Mestrado em Saúde Pública) - Universidade Estadual da Paraíba, Campina Grande.

Moreira, T. R. S. R. (2015). A emergência dos tóxicos como um problema social no início do século XX. Dissertação (Mestrado e História) - Instituto de Filosofia e Ciências Humanas da Universidade Estadual de Campinas (p. 31-34). Campinas.

Mosquera, J, T., \& Menéndez, M. C. (2005). Efectos toxicológicos y Neuropsiquiátricos producidos por consumo de cocaína. Rev. Fac. Med, Bogotá, 53(1), $10-26$.

Oliveira, L. G., \& Nappo, S. A. (2008). Caracterização da cultura de crack na cidade de São Paulo: padrão de uso controlado. Rev. Saúde Pública, 42(4), 664671.

Passagli, M. (2013). Toxicologia forense: teoria e prática. (4a ed.): Millenium.

Polícia Científica (2018). Instituto de Polícia Científica. Desenvolvido por Gabriel Rolim. https://policiacivil.pb.gov.br/orgaos-delegacias/instituto-de-policiacientifica

Política Nacional Sobre Drogas - PNAD (2019). Ministério da Justiça e Segurança Pública. https://justica.gov.br/sua-protecao/politicas-sobredrogas/politicas-sobre-drogas-1

Portal Médico. Conselho Federal de Medicina. Desenvolvido pelo Conselho Federal de Medicina, 1951-2019. Elaborada com participação do CFM e da ABP, nova política nacional sobre drogas entra em vigor. https://portal.cfm.org.br/index.php?option=com_content\&view=article\&id=28172:2019-04-18-21-41$06 \&$ catid $=3$

Pozner, C. N., Levine, M. D., \& Zane, R. (2005). The cardiovascular effects of cocaine. The Journal of Emergency Medicine, 29(2), 173-178.

Queiroz, M. V. D. (2008). Quem te vê não te conhece mais: arquitetura e cidade de Campina Grande em transformação (1930-1950). Dissertação (Mestrado em Teoria e História da Arquitetura e do Urbanismo) - Escola de Engenharia de São Carlos, Universidade de São Paulo, São Carlos.

R Core Team (2019). R: A language and environment for statistical computing. R Foundation for Statistical Computing, Vienna, Austria. https://www.Rproject.org/.

Rio De Janeiro (1938). Decreto n. 891, de 25 de novembro de 1938. Aprova a Lei de Fiscalização de Entorpecentes. Coleção de Leis do Brasil, 4 , 148.

Rodrigues, S. V. N. (2010). Caracterização química e análise quimiométrica de amostras de cocaína apreendidas em Minas Gerais pelo Departamento de Polícia Federal. Monografia (Bacharel em Química) - Universidade Federal de Minas Gerais, Belo Horizonte - MG.

Scientific Working Group for the Analysis of Seized Drugs (2014). United States Department of Justice Drug Enforcement Administration, Washington. https://www.swgdrug.org/Documents/SWGDRUG\%20Recommendations\%20Version\%207-0.pdf

Siegel, S. \& Castellan, N. J (2006). Estatística Não Paramétrica para as Ciências do Comportamento. Artmed Bookman.

Silva, P. P. C., \& Chao, C. H. N. (2009). Bairro José Pinheiro: uma história de lazer e cultura popular limitada pela violência. In: Lemos, E. M. B. C., Dantas, E. R., \& Chao, C. H. N. De portas abertas para o lazer: a cultura lúdica nas comunidades de Bairro. (p. 184): EDUEPB. ISBN 978-85-7879-026-4.

Silva, T. C. A. (2014). Análise descritiva aplicada aos principais crimes ocorridos no município de Campina Grande - PB 2012 e 2013 . Trabalho de Conclusão de Curso (Graduação em Estatística)- Universidade Estadual da Paraíba, Campina Grande. 
Research, Society and Development, v. 10, n. 3, e48610313571, 2021

(CC BY 4.0) | ISSN 2525-3409 | DOI: http://dx.doi.org/10.33448/rsd-v10i3.13571

Sistema De Informação De Agravos De Notificação - SINAN (2017). http://tabnet.datasus.gov.br/cgi/tabcgi.exe?sinannet/cnv/Intoxbr.def

Skaba, D. A., Carvalho, M. S., Barcellos, C., \& Martins, P. C. (2004). Geoprocessamento dos dados da saúde: o tratamento dos endereços. Cad Saúde Pública, 20:1753-6.

Torcato, C. E. M. (2016). A história das drogas e sua proibição no Brasil: da Colônia à República. Tese (Doutorado em História) - Faculdade de Filosofia, Letras e Ciências Humanas da Universidade de São Paulo. p. 101.

United Nations Office On Drugs And Crimes (UNODC). World Drug Report 2018: UNODC. 